\title{
THE TEACHING OF HISTORICAL GEOLOGY ${ }^{1}$
}

\author{
BY HERDMAN F. CLELAND
}

(Read before the Society December 31, 1919)

\section{CONTENTS}

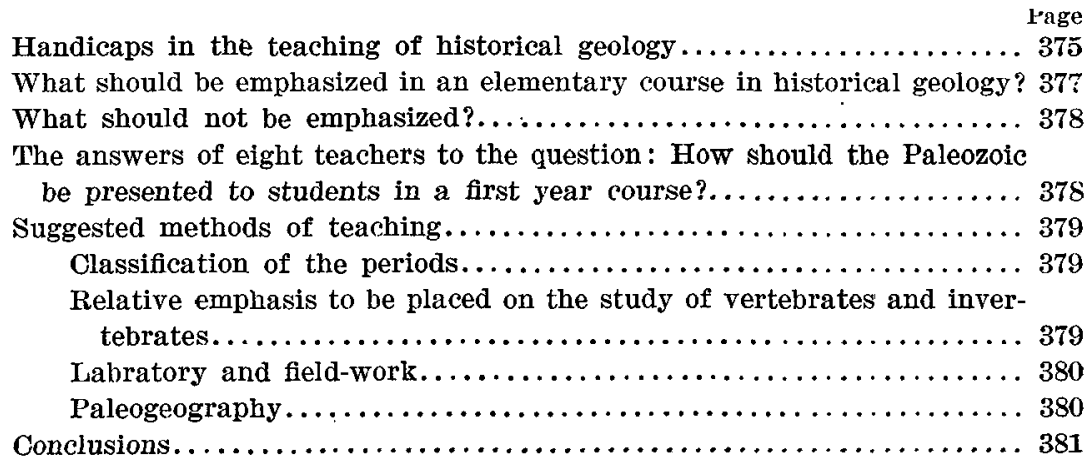

\section{Handioars in the Teaching of historical Geology}

The first instruction in paleontology which most students receive is in elementary historical geology. The exception to this rule is afforded by those alert young men who become interested in the fossils of their home region and learn about them from State and government reports without first having received preliminary instruction. Some of our most eminent paleontologists had their interest aroused in this way and are true products of their environment. J. M. Clarke, Charles Schuchert, Edward 0 . Ulrich, and Charles D. Walcott are examples. Notwithstanding these notable exceptions, most persons who obtain a preliminary knowledge of paleontology acquire it in a first course in historical geology, and it is on the teaching of this subject that I am to speak.

There are few courses in the teaching of which the instructor is so severely handicapped as in the one under discussion, and the most serious obstacle lies in the lack on the part of the students of a preliminary

\footnotetext{
1 Manuscript received by the Secretary of the Society January 5, 1920.

This paper is one of a series composing a symposium on the teaching of geology and paleontology.
} 
knowledge of the classification of the plants and animals which form the basis for an important part of the work. Under the most favorable conditions, the student may have had one or more courses in biology, but in these courses he learned more about cells, heredity, and evolution than about forms and their classification. One will be conservative in stating that not one student in fifty who elects geology possesses a knowledge of a classification of plants and animals that will be really helpful to him in his study of historical geology. Such important Paleozoic animals as brachiopods, trilobites, bryozoans, crinoids, cystoids, graptolites, and oldstyle corals are given bare mention, if mentioned at all, in courses in elementary biology. Consequently, biology as a prerequisite to historical geology is of little value. It is because of this ignorance of those invertebrates which must necessarily be discussed that every teacher of historical geology heaves a sigh of relief when the Paleozoic is completed or, at least, when the Pennsylvanian is reached.

As a result of the student's ignorance of biological classification, he has a vocabulary hurled at him, almost as soon as he begins his study of historical geology, which discourages the earnest and frightens the dull, and it is not until the Cambrian, Ordovician, and Silurian are passed that the class begins to find solid ground. I am assuming that the course is largely confined to the study of the classes and orders of animals and plants, and that the student is not required to learn much about species and genera. I think we too often fail to realize that even group names, such as brachiopod, gastropod, and trilobite, do not immediately call up a definite image to most students until quite late in the course, and consequently when the teacher lectures about them or brings them into his discussions he is not fully comprehended. Until each group studied does call up a definite image to the student, he can not, of course, become interested in the life of the past. An extreme example will illustrate this difficulty. A well known geologist, an excellent teacher, was asked by a student, during the study of the reptiles of the Mesozoic, if these animals had skins when they were alive or if they were always skeletons.

As the time allotted to historical geology in most colleges and universities is three hours a week for one semester, it is evident that the teacher can not devote many lectures and laboratory exercises to the teaching of classification and the descriptions of animals and plants. One of two ways of teaching this necessary classification is used: the teacher either gives preliminary lectures or laboratory work on the entire classification, and thus quickly gets it out of the way before going on with the substance of the course, or he takes it up a little at a time, as the subject requires. When this latter method is followed he spends a disproportionate time on the Cambrian and Ordovician, since in the dis- 
cussion of these two periods most of the invertebrates are studied for the first time. I am assuming that the subject is taught in the conventional way.

Another handicap to the successful teaching of historical geology in many educational institutions is that the teacher is not a paleontologist and has not had adequate training in the science. Moreover, as his major interest is in some other branch of geology, he seldom gives an interesting course in this subject.

Even the stratigrapher may be somewhat at a disadvantage in teaching this elementary course, because if he does not hold himself in check he is likely to find himself spending too much time on the details of paleontology and stratigraphy. To him the specific names of certain fossils, because of their great value in the correlation of certain formations, may seem more important than anything else and he may smother his class in technicalities.

The ideal gateway to paleontology is such a course as that outlined in Shimer's "Introduction to the Study of Fossils." To teach historical geology to students who had mastered such a course would be a pleasure. The objection to such a prerequisite is that few students would elect it, with the resultant practical elimination of elementary historical geology-one of the most valuable cultural subjects offered in college curricula.

\section{What shodld be EmpHasized in an elementary Codrse in HISTORICAL GEOLOGY?}

In preparing this paper I found myself repeatedly asking: What would you want to learn from a course in historical geology if you could take but one course and would never again have an opportunity to make a further study of the subject? In other words, what should a study of historical geology contain for a very large proportion of the students who elect it? This is a fair question because very few students go on with paleontology. This being true, our attention should be given to the ninety and nine rather than to the one.

Our answer might be somewhat as follows:

(1) I would want to have a knowledge of the proofs and progress of evolution as shown by the life of the past.

(2) I would want to understand the effects of physical conditions in bringing about the modifications of the form and structure of organisms.

(3) I would want to acquire a general knowledge of the succession of life-that is, to learn how time after time in the history of the world great classes of animals and plants predominated and then either disappeared never again to return or ever after took a subordinate place. 
(4) I would want to be shown how the sedimentary series was built up, how it varied in composition, and why; how the ages of the strata are determined, and how the work of correlation is accomplished.

(5) I would want to learn about the climates of the past and how this knowledge is obtained from a study of fossils and other evidence.

(6) I would want to carry away with me a general idea of the evolution of the continents.

Topics such as these are the ones which, it seems to me, should be emphasized in a cultural course, such as is offered in all of our institutions of higher learning.

\section{What SHOULD NOT BE EMPHASIZED?}

The most difficult part of historical geology for the.student, as has been said, is the Paleozoic, because he knows so little about the invertebrates found in the rocks of this group and has little interest in them. Am I a heretic if I ask, "Why should he?" These fossils are interesting largely because of their value in chronology and correlation and because of the lessons they teach of evolution. But these first year students do not have a sufficient knowledge of the structure and characteristics of these animals to appreciate or understand their evolutional value and few will have acquired such a knowledge when the course is passed. These are the facts. Why not face them?

One reason that students are required to spend so much time on invertebrates is that we are to some extent. following the method of teaching in geology which used to be employed in the teaching of human history. Not many years ago the student in history was required to learn the number of men engaged in each battle, the names of the generals, the number of men killed and wounded in each engagement, the line of march, and other easily forgotten statistics, whereas the bearings of these events upon the progress of civilization were too often merely touched upon or omitted. Our method of teaching geology is largely inherited from the time when fossils were regarded as of value largely because they are indicators of chronology. This is shown in the treatment of the Prleozoic as given in all text-books of geology.

The Answers of eight Teachers to the Question: How should the Paleozold be PResented to Students in the FIRST IEAR COURSE?

Some months ago, before I was asked to speak on this subject, I wrote to seven paleontologists and have since spoken to one other, who are also successful teachers of general geology, asking, among other questions, 
how, in their opinion, the Paleozoic should be presented to students in a first year course. The answers are interesting and are worthy of the careful consideration of those who teach this subject. Two of these teachers were of the opinion that the discussion of the animals and plants of the Paleozoic should be by periods rather than by eras - that is, the life of the Paleozoic should be treated from the stratigraphic rather than from the biologic point of view. They believe the subject has, on the whole, been properly presented ever since geology became a science. As one says: "Doubtless a student would get a better idea of the animal or plant groups by having each discussed as a unit, but he would fail to grasp the geological significance of the group." Two of the eight teachers favored grouping together the life under two divisions, the late and early Paleozoic, perhaps under such heads as Eo-Paleozoic and NeoPaleozoic. This they considered desirable because for beginners there is hardly enough difference between the Cambrian and Ordovician faunas, for example, to make it worth while to point out distinctions. On the other hand, the changes between the Cambrian and Permian are rather too great to go unnoticed until the end of the discussion of the Paleozoic era. Four advocated the gathering together of the life of the Paleozoic in one place and the physical history in another. There is much to be said for this last suggestion, but the danger of losing the geological significance of the group is great. Moreover, with this presentation the student might become confused because of the large number of periods which would necessarily be discussed with each class of animal or plant.

\section{Suggested Methods of Teaching}

\section{CLASSIFIOATION OF THE PERIODS}

All things considered, it seems desirable to change our method of presenting the material for the study of this difficult era, and my belief at present is that beginning students would have less trouble and would learn more of value if the animals and plants were grouped together under earlier, or Eo-Paleozoic, and later, or Neo-Paleozoic. If this were done, much repetition could be avoided and the descriptions and classification of Paleozoic plants and animals could be made much easier and more interesting, while time would be left for the acquiring of a knowledge of the subjects mentioned a few minutes ago.

\section{RELATIVE EMPHASIS TO BE PLACED ON THE STUDY OF VERTEBRATES} AND INVERTEBRATES

There is an interesting inconsistency in the argument that the invertebrates of the Paleozoic should be discussed by periods, and that much 
time should be spent on them. This is shown in the discussion of the Mesozoic and Cenozoic in text-books of geology. I think no one will deny that the invertebrates of all eras are of nearly equal rank as index fossils and for the lessons of evolution that they teach. Nevertheless, they are given relatively little attention in the discussion of the Mesozoic and Tertiary. The explanation for this difference of treatment is to be found in the fact that the vertebrates are more interesting, more important, and present more striking lessons in evolution. Nevertheless, some teachers spend so much time on the Paleozoic invertebrates that they are obliged to give an inadequate amount of time to the study of the Mesozoic and Tertiary and of the great lessons that are there taught.

\section{LABORATORY AND FIELD-WORK}

Some laboratory work should, of course, be required of all students who elect historical geology. If our educational institutions were all situated in fossiliferous regions, as is Cornell University, the University of Cincinnati, and the University of Texas, the teaching of paleontology and stratigraphy would be simplified. Prof. G. D. Harris, perhaps more than any one else, has made much of this fortunate situation. Even the first year student wants to know the names of the fossils he himself discovers, the age and the name of the rock in which they occur, and how it was formed. Unfortunately, most institutions of learning are not so favorably situated and it is necessary for the teacher to use labeled specimens in the laboratory. Fossils, rather than casts, are necessary. Theoretically, the cast of a well preserved fossil, or a restoration, is better than an imperfect fossil ; but, as every teacher has learned, the elementary student can not be convinced of this fact. He wants the real thing and loses interest if he does not have it. Consequently, where historical geology is taught there should be a set of fossils for laboratory use. More should be made of lantern slides than has hitherto been done, and especially is this desirable in a study of the vertebrates. There are many instructive and striking restorations of which slides can be made. Unfortunately, a great deal of time is required to get this material together, and this Society would do a great kindness to teachers of paleontology if such a set were made available.

\section{PALEOGEOGRAPHY}

I fear to express an opinion on the teaching of paleogeography for fear that you will think that I have left all hope behind; but I am looking for difficulties and for the best way out of them. In order to apply the Taylor efficiency methods in our teaching as it is employed in manufac- 
turing, it is first necessary to find the faults in our systems. No topic in historical geology is more abused than that of paleogeography. This is true because most teachers do not realize how uncertain are the boundaries of the lands and seas on the published paleogeographic maps. The result is that students are sometimes required to learn a great deal that is based on very uncertain evidence or much that will later be changed, or which may already have been abandoned by those who are working on the subject.

There are two suggestions for the teaching of paleogeography to elementary students that are at least worth our consideration. One is that the paleogeography of a single period should be chosen as a type and should be thoroughly studied. In this way the student would get a better grasp of the changes in geography that have taken place in a single period, and from this as a type could form a better idea of the paleogeography of other periods. A second suggestion is that the regions of general submergence should be emphasized. The method usually adopted is to require the student to learn the boundaries between the seas and lands of each period as given in the most recent paleogeographic maps. As in the study of invertebrates, the teacher must put himself in the place of the student and ask himself, "Is all of the work required worth the student's time and effort?" If it is found that some of it is not, it should, of course, be omitted or rearranged. It is evident that the paleogeography of the region in which the college or university is situated should be emphasized. One obstacle in selecting the material to be presented is that few geologists have an extended knowledge of paleogeography, and consequently do not know what is hypothetical and what is based on fact.

\section{ConcLUSIONS}

I do not wish to touch on a controversial subject, but one can not fairly dismiss the topic before us without doing so. I refer to the seemingly growing practice of permitting a student to elect either physical geology or physiography as a first course, and later allowing the same student to choose as a second course whichever of these two he had not taken. Any one who has looked over the text-books of physical geology and physiography must be impressed with the large amount of material in the one which is duplicated in the other. Certainly one-half, possibly three-fourths, of the subject-matter is the same in the two. It is not my purpose to discuss the advisability of eliminating the one or the other of these courses, but to ask you to think about this question: Would not 
every student, without exception, receive vastly greater benefit from a year's course in physical geology and historical geology, or physiography and historical geology, than from a semester course in physical geology and a second course in physiography, or vice versa? The answer seems obvious. It is to be hoped that every effort will be made by teachers to prevent the present tendency to divorce historical from physical geology. Such a separation would be most unfortunate, because a student who has had physical geology and has not had historical geology has been deprived of a conception of time, of the progress of life, of evolution, of the growth of continents, and of other subjects which every educated man should have. The principal reasons that physical geology and historical geology are not offered as a single-year course in all of our colleges and universities appear to be two: First, historical geology does not draw as large electives as physical geology or physiography, because it is a more difficult subject for the student to acquire; and, second, most teachers of general geology have had little training in paleontology, and consequently slight this subject for one in which they are more interested. Some of the blame for this shyness of the student in electing historical geology, as has been stated, should be placed on the teachers and text-book writers, who have been making the course too largely a test of memory, and who have been requiring the class to learn a great deal that, for the student who takes the course for its cultural value, is, frankly, not worth his time and effort. Nevertheless, the subject as now taught, with all its imperfections, is well worth the time of any student. We are, I think, passing through a transitional stage, from which the subject will soon emerge as one of the broadest, most valuable, most interesting, and most cultural that will be offered in colleges and universities. 